\title{
限定された需要情報のもとでの多期間生産計画に関する 一考察*
}

\author{
川崎 雅也 $^{\dagger} \cdot$ 竹本 康彦 $^{\dagger} \cdot$ 上野 信行 $^{\dagger} \cdot$ 有薗 育生 ${ }^{\ddagger}$
}

\section{A Study of Multi-period Production Planning under Limited Information about Demand*}

Masaya KAWASAKI ${ }^{\dagger}$, Yasuhiko TAKemoto ${ }^{\dagger}$, Nobuyuki Ueno $^{\dagger}$ and Ikuo Arizono

\section{1. はじめに}

サプライ・チェーンに存在する樣々な問題を解決する一 つのアプローチとして情報共有がある .たとえば , メー カでの生産計画をサプライヤに提示して , 合理的に納品 日や納品量を決定し，不良在庫や欠品を減らす取り組み があげられる．自動車業界において，サプライヤに生産・ 販売計画を内示したり，共同のコスト削減プログラムを 立ち上げたりし , サプライ・チェーン全体の利益向上に 成功した事例が報告されている $[1]$.

自動車部品などの製品において , サプライヤでの製造 リードタイムがメーカの納入リードタイムより長期に及 ぶことがある．このとき，サプライヤでは事前に製品を 生産し在庫として保有する見込生産方式が採用される． 前述のとおり，この状況で効率的に生産活動を営むにあ たって , サプライ・チェーン環境にある企業間では数期 間先に予定の注文に関する情報が内示として事前に通知 される場合がある．ただし，需要には不確実性が存在す る. 従来の研究では, 事前の需要情報に対して, 内示を 平均, 履歴から分散を考慮し, さらに各期での需要分布 として正規分布やガンマ分布などを想定し生産計画が立 案されていた $[2,3]$. ただし，数期間における需要分布を 精度よく予測することは難しく，また想定した需要分布 が適当でなかった場合のリスクの問題がある.

限定された需要情報に基づき生産計画を立案する 方法として, 需要の平均と分散の情報のみを利用する Distribution Free Approach(DFA)[4] はよく知られた 手法である .これまでに, 新聞売り子問題や定量発注方

* 原稿受付 2009 年 6 月 12 日

†県立広島大学 経営情報学部 Faculty of Management and Information Systems, Prefectural University of Hiroshima; 1-1-71, Ujina-Higashi, Minami-ku, Hiroshima city, Hiroshima 734-8558, JAPAN

‡ 大阪府立大学 大学院 工学研究科 Graduate School of Engineering, Osaka Prefecture University; 1-1 Gakuencho, Naka-ku, Sakai city, Osaka 599-8531, JAPAN

Key Words: distribution free approach, min-max discipline, multi-period production planning.
式などの各種在庫システム，また単一期間の生産計画に 応用されてきた $[5,6]$. 本研究では, 需要に関する平均と 分散の情報のみを利用し, 多期間に及ふぶ生産計画の策定 方法について検討する .このとき，需要分布を想定した 場合との比較により，限定された情報より策定される計 画の有効性について言及する .

\section{2. 記号の定義および仮定}

本研究では, 内示として需要情報が事前に通知される サプライ・チェーン環境にある企業を対象とする．ただ し , サプライヤでの製造リードタイムはメーカの納入 リードタイムより長く，見込生産方式が採用されている とする . 内示は不確実であり, 少のため各期の確定注文 は内示に対してばらつくとする .このような状況におけ る多期間生産計画モデルを考える. 以下に本研究での仮 定と記号を定義する .

\section{1 仮定}

(i) メーカからサプライヤへの需要に関して, 各期の需 要は独立である .メ一カから事前に内示 (注文予定 数) の提示はあるが, 納入指示 (確定注文数) は内 示より変動する . 提案法では需要の分布形は未知 とし，想定しない，ただし，与えられている唯一 の情報である内示を平均とし, 分散は過去の履歴 より既知とする.

(ii) サプライヤの製造リードタイムは, メーカより要 求される納入リードタイムよりも長いと仮定する. サプライヤでは, 事前に提示される内示をもとに 見込生産方式が採用されるものとする .

（iii）内示の情報から $n$ 期間の生産計画を立案する .

(iv) 未処理需要は, 品切れに伴う損失が計上された上 でバックオーダされる .

\section{2 記号の定義}

$i$ ：期間 .ただし,$i \leq n$.

$d_{i}: i$ 期での需要量 . ただし, 各期の需要分布の確率密 度関数および分布関数を $f_{i}(z), F_{i}(z)$ とする.

$\mu_{i}: i$ 期での需要に関する内示 . ただし, 需要分布の平 
均值と一致する.

$\sigma_{i}: i$ 期での需要の標準偏差 .

$x_{i}: i$ 期での製品の完成数 .

$S_{0}$ : 初期在庫量 .

$S_{i}: i$ 期での在庫量 . $S_{i}=S_{0}+\sum_{t=1}^{i} x_{t}-\sum_{t=1}^{i} d_{i}$.

$y^{+}: \max \{0, y\} \cdot E[y]^{+}=E\left[y^{+}\right]$.

$y^{-}: \max \{0,-y\} \cdot E[y]^{-}=E\left[y^{-}\right]$.

$h_{i}: i$ 期での単位製品・単位時間あたりの在庫保管費用 . $b_{i}: i$ 期での単位製品・単位時間あたりの品切れ損失 .

\section{3. モデルの定式化}

ここでは，需要分布を想定し生産計画を策定する方法 と, 需要分布を想定せず需要の内示および分散のみの情 報をもとに生産計画を策定する方法を説明する．

\section{1 需要分布を想定した場合の定式化と解法} 生産計画では，需要分布を想定した場合の期待費用関 数を在庫保管費用と品切れ損失により構筑し，これを最 小化することを考える . 具体的に, 期待費用関数を

$$
C(\hat{x})=\sum_{i=1}^{n}\left(h_{i} E\left[S_{i}\right]^{+}+b_{i} E\left[S_{i}\right]^{-}\right)
$$

として定義する .ただし,$\hat{x}=\left(x_{1}, x_{2}, \cdots, x_{n}\right)$ である . ま た，非負制約 $x_{i} \geq 0$ を満足する必要がある.ここで， $D_{i}=\sum_{t=1}^{i} d_{t}$ とする . (1) 式における $E\left[S_{i}\right]^{+}$は

$$
\begin{gathered}
S_{0}+\sum_{t=1}^{i} x_{t} \\
E\left[S_{i}\right]^{+}=\int_{0}^{S_{0}+\sum_{t=1}^{i} x_{t}} S_{i} f^{(i)}\left(D_{i}\right) d D_{i}=\int_{0}^{F^{(i)}}\left(D_{i}\right) d D_{i}
\end{gathered}
$$

として与えられる.ただし,$f^{(i)}(y)$ は $i$ 期までの需要分 布の確率密度関数の畳み込みを意味し，

$$
\begin{aligned}
& f^{(1)}(y)=f_{1}(y) \\
& f^{(i)}(y)=\int_{0}^{y} f^{(i-1)}(y-z) f_{i}(z) d z
\end{aligned}
$$

より定義されるものである . また,$F^{(i)}(y)$ は $f^{(i)}(y)$ の 分布関数である.一方, $E\left[S_{i}\right]^{-}$は定義より

$$
E\left[S_{i}\right]^{-}=E\left[S_{i}\right]^{+}-E\left[S_{i}\right]
$$

として与えられる.結局，目的関数 (1) と非負制約 $x_{i} \geq 0$ をもつ確率計画問題として定式化することができ，最適 生産計画 $\hat{x}^{*}=\left(x_{1}^{*}, x_{2}^{*}, \cdots, x_{n}^{*}\right)$ を

$$
x_{i}^{*} \frac{\partial C}{\partial x_{i}}\left(x_{1}^{*}, \cdots, x_{n}^{*}\right)=0, \quad \forall i=1, \cdots, n
$$

より得ることができる . (1) 式は凸関数であることから， 各 $x_{i}^{*}$ は (6) 式を満足する内点解あるいは端点解として 与えられ [7], この組合せにより最適解 $\hat{x}^{*}$ が求められる. ただし，(2) 式から畳み込みによる需要分布の分布関数 が必要となる．正規分布やガンマ分布の場合では，光の
再生性より比較的容易に分布関数を考えることができる． 一方, 一樣分布のように再生性を有しない分布を想定す る場合には非常に煩杂雑な計算が必要である $[8]$.

3.2 需要分布を未知とした場合の定式化と解法 前述では需要情報に分布関数を想定し定式化されてい る.しかし , 数期間における需要分布を精度よく予測す ることは難しく，想定した需要分布が適当でなかった場 合のリスクの問題も存在する . また，需要分布を特定し た場合，正規分布のように再生性がある分布に関しては， 計算は容易に求めることができる一方, 再生性がない分 布においては，畳み込み演算を行う必要がある．

ここで, Cauchy-Schwarz の不等式を考慮することで

$$
E\left|S_{i}\right| \leq\left\{E\left[S_{i}^{2}\right]\right\}^{1 / 2}
$$

の関係を得る。ただし，|y|は $y$ の絶対値を意味し， $E|y|=E[|z|]$ と表記している.さらに $E\left[S_{i}\right]^{+}$は

$$
E\left[S_{i}\right]^{+}=\frac{E\left|S_{i}\right|+E\left[S_{i}\right]}{2}
$$

である . (5)式の関係を考慮することで, (1)式から

$$
\begin{aligned}
C(\hat{x})= & \sum_{i=1}^{n}\left(\frac{h_{i}+b_{i}}{2} E\left|S_{i}\right|+\frac{h_{i}-b_{i}}{2} E\left[S_{i}\right]\right) \\
\leq & \sum_{i=1}^{n} \frac{h_{i}+b_{i}}{2}\left\{E\left[S_{i}^{2}\right]\right\}^{1 / 2}+\sum_{i=1}^{n} \frac{h_{i}-b_{i}}{2} E\left[S_{i}\right] \\
= & \sum_{i=1}^{n}\left\{\sum_{t=1}^{i} \sigma_{t}^{2}+\left(S_{0}+\sum_{t=1}^{i} x_{t}-\sum_{t=1}^{i} \mu_{t}\right)^{2}\right\}^{1 / 2} \\
& +\sum_{i=1}^{n} \frac{h_{i}-b_{i}}{2}\left(S_{0}+\sum_{t=1}^{i} x_{t}-\sum_{t=1}^{i} \mu_{t}\right) \\
\equiv & C_{\mathrm{DFA}}(\hat{x})
\end{aligned}
$$

を得ることができる． $C_{\mathrm{DFA}}(\hat{x})$ は $C(\hat{x})$ の上限を与える . ここで, 非負制約 $x_{i} \geq 0$ のもと， $C_{\mathrm{DFA}}(\hat{x})$ の最小化を図 り，代替的な最適解を得ることを考える。具体的に，(9) 式は凸関数であることから, 各 $x_{i}^{*}$ は

$$
x_{i}^{*} \frac{\partial C_{\mathrm{DFA}}}{\partial x_{i}}\left(x_{1}^{*}, \cdots, x_{n}^{*}\right)=0, \quad \forall i=1, \cdots, n
$$

を満足する内点解あるいは端点解として与えられ $[7]$, こ の組合せにより最適解 $\hat{x}^{*}$ が求められる.この方法は， 同じ平均・分散を有する分布の中で最悪な状況におい て最適化を図るMin-Max 規範に基づく最適化を提案す るものである .この方法がDistribution Free Approach (DFA)[4] とよばれるものである .

\section{4. 数值検証}

(1) 式の $C(\hat{x})$ および $(9)$ 式の $C_{\mathrm{DFA}}(\hat{x})$ より求まる生 産計画について検証する . $n=5$ 期間を対象に，需要分布 として正規分布, ガンマ分布, 一樣分布を想定し, 数值 実験を行った .ただし，各期の内示および分散を Table 1 
に示す．

Table 2 および 3 は, 需要分布として正規分布, ガン マ分布，一樣分布を想定した場合の (1) 式の期待費用関 数 $C(\hat{x})$ を最小化する最適生産計画 $\hat{x}^{*}$ と DFA に基づく (9) 式の期待費用関数 $C_{\mathrm{DFA}}(\hat{x})$ を最小化する代替的最適 生産計画 $\hat{x}_{\mathrm{DFA}}^{*}$ を示している.ただし, 正規分布, ガン マ分布，一樣分布を想定した場合の最適生産計画を区別 するために，各分布を想定した場合の最適生産計画 $\hat{x}^{*}$ を $\hat{x}_{\mathrm{N}}^{*}, \hat{x}_{\mathrm{G}}^{*}, \hat{x}_{\mathrm{U}}^{*}$ と表記する .

さらに, 最適生産計画での期待費用関数値について検 討する .たとえば , パラメータ $h_{i}=1, b_{i}=10, S_{0}=0$ において，需要分布に正規分布を想定した場合に最適生 産計画 $\hat{x}_{\mathrm{N}}^{*}$ を採用したときの期待費用関数值 $C\left(\hat{x}_{\mathrm{N}}^{*}\right)$ は 527.8 である.一方，需要分布に正規分布を想定した場 合に代替的最適生産計画 $\hat{x}_{\mathrm{DFA}}^{*}$ を採用したときの期待費 用関数値 $C\left(\hat{x}_{\mathrm{DFA}}^{*}\right)$ は 529.7 である. $C\left(\hat{x}_{\mathrm{DFA}}^{*}\right)$ が $C\left(\hat{x}_{\mathrm{N}}^{*}\right)$ より大きいことは明らかである $. C\left(\hat{x}_{\mathrm{DFA}}^{*}\right)-C\left(\hat{x}_{\mathrm{N}}^{*}\right)$ は分 布に関する知識を得るために投資できる最大費用に対応 する. すなわち , 分布の特定にこれ以上費用がかかるよ うであるなら，限定された情報から最適生産計画を立案 するのが経済的であるといえる. Table 4 および 5 にお いて , 各種需要分布のもとでの同樣の数值結果を与えて

Table 1 期別内示と分散

\begin{tabular}{c|c|c|c|c|c}
\hline 期 & 1 & 2 & 3 & 4 & 5 \\
\hline 内示 & 100 & 100 & 100 & 100 & 100 \\
\hline 分散 & $35^{2}$ & $35^{2}$ & $35^{2}$ & $35^{2}$ & $35^{2}$ \\
\hline
\end{tabular}

Table 2 最適生産計画の比較 $\left(h_{i}=1, b_{i}=10, S_{0}=0\right)$

\begin{tabular}{c|c|c|c|c|c}
\hline$\hat{U}$ & 1 & 2 & 3 & 4 & 5 \\
\hline$\hat{x}_{\mathrm{N}}^{*}$ & 146.7 & 119.4 & 114.9 & 112.5 & 111.0 \\
$\hat{x}_{\mathrm{G}}^{*}$ & 149.1 & 119.6 & 115.0 & 112.6 & 111.1 \\
$\hat{x}_{\mathrm{U}}^{*}$ & 149.6 & 120.0 & 113.3 & 112.2 & 110.9 \\
\hline$\hat{x}_{\mathrm{DFA}}^{*}$ & 149.8 & 120.6 & 115.8 & 113.4 & 111.8 \\
\hline
\end{tabular}

Table 3 最適生産計画の比較 $\left(h_{i}=1, b_{i}=15, S_{0}=0\right)$

\begin{tabular}{c|c|c|c|c|c}
\hline 期 & 1 & 2 & 3 & 4 & 5 \\
\hline$\hat{x}_{\mathrm{N}}^{*}$ & 153.7 & 122.2 & 117.1 & 114.4 & 112.7 \\
$\hat{x}_{\mathrm{G}}^{*}$ & 158.3 & 122.5 & 117.2 & 114.5 & 112.7 \\
$\hat{x}_{\mathrm{U}}^{*}$ & 153.0 & 125.3 & 116.1 & 113.9 & 112.6 \\
\hline$\hat{x}_{\mathrm{DFA}}^{*}$ & 163.3 & 126.2 & 120.1 & 117.0 & 114.9 \\
\hline
\end{tabular}

Table 4 期待費用関数値の比較 $\left(h_{i}=1, b_{i}=10, S_{0}=0\right)$

\begin{tabular}{c|c|c|c}
\hline 需要分布 & $C\left(\hat{x}^{*}\right)$ & $C\left(\hat{x}_{\mathrm{DFA}}^{*}\right)$ & 差 \\
\hline 正規分布 & 527.8 & 529.7 & 1.9 \\
\hline ガンマ分布 & 574.6 & 575.1 & 0.5 \\
\hline 一樣分布 & 513.7 & 514.5 & 0.8 \\
\hline
\end{tabular}

Table 5 期待費用関数値の比較 $\left(h_{i}=1, b_{i}=15, S_{0}=0\right)$

\begin{tabular}{c|c|c|c}
\hline 需要分布 & $C\left(\hat{x}^{*}\right)$ & $C\left(\hat{x}_{\mathrm{DFA}}^{*}\right)$ & 差 \\
\hline 正規分布 & 576.9 & 595.7 & 18.8 \\
\hline ガンマ分布 & 636.7 & 644.6 & 7.9 \\
\hline 一樣分布 & 552.7 & 574.4 & 21.7 \\
\hline
\end{tabular}

おく. Table 4 および 5 から, 品切れに対する損失が厳 格である場合, 需要分布の特定に尽力するのが得策であ ることが推察できる.

\section{5. おわりに}

本研究では, サプライヤでの製造リードタイムがメー カの納入リードタイムより長い場合に, メーカよりサプ ライヤに需要に関する内示が与えられているときの多期 間生産計画問題について考察した . 従来の研究では, 内 示を平均, 履歴から分散を考慮し, さらに各期での需要 分布として正規分布やガンマ分布などを想定し生産計画 が立案されていた .ただし , 数期間における需要分布を 精度よく予測することは難しく，また想定した需要分布 が適当でなかった場合のリスクの問題がある . 本研究で は, 需要に関する平均と分散の情報のみを利用し, 多期 間に及っ泩産計画の策定方法について考察した .さらに， 需要分布を想定した場合との比較により，限定された情 報より策定される計画の有効性について, 数值例を通じ て検証した，一方，多期間に及心濡要を考慮する場合， 需要間の相関の存在が懸念される．これを考慮したモデ ルは今後の課題として検討していきたい .

謝 辞 本研究の一部は平成 20- 22 年度科学研究補助金基 盤研究 (C) (No.20510138) の補助を受けたことを記し てここに謝意を表します．

\section{参 考文 献}

[1] 曹 , 中島 , 竹田 , 田中 : サプライチェーンマネジメント 入門, 朝倉書店 (2008)

[2] 上野, 古田, 奥原, 渋木, 倉本 : マスカスタマイゼーショ ン対応の生産管理システムの提案 ; システム制御情報学 会論文誌, Vol.17, No.6 ,pp.221-229 (2004)

[3] 上野, 佐野: 需要がガンマ分布の場合におけるマスカ スタマイゼーション対応の生産計画法 (MCPS-Ga) ; 第 51 回システム制御情報学会研究発表講演会講演論文集, pp.85-86 (2007)

[4] I. Moon and G. Gallego: Distribution free procedures for some inventory models; J. Opl. Res. Soc., Vol.46, No.6, pp.651-658 (1994)

[5] E. A. Silver and I. Moon: The multi-item single period problem with an initial stock of convertible units; Eur. J. Oprl. Res., Vol.132, pp.466-477 (2001)

[6] H. K. Alfares and H. H. Elmorra: The distribution-free newsboy problem: extensions to the shortage penalty case; Int. J. Prod. Econ., Vol.93-94, pp.465-477 (2005)

[7] 岡田: 経済学・経営学のための数学, 東洋経済新聞社 (2001)

[8] F. Killmann and E. Collani: A note on the convolution of the uniform and related distributions and their use in quality control; Econ. Qual. Ctrl., Vol.16, pp.17-41 (2001) 